\title{
New species of Ablabesmyia Johannsen (Diptera, Chironomidae, Tanypodinae) from the Neotropical Region, with description of male adults and immature stages
}

\author{
Caroline S. N. Oliveira \& Alaíde A. Fonseca-Gessner
}

Departamento de Hidrobiologia, Centro de Ciências Biológicas e da Saúde, Universidade Federal de São Carlos. Caixa Postal 676, 13565-905 São Carlos, São Paulo, Brasil. Email: cneubern@yahoo.com.br; gessner@power.ufscar.br

\begin{abstract}
A new species of genus Ablabesmyia is described. The larvae were collected associated with aquatic macrophytes in ponds from the Southeast of Brazil. In laboratory, the larvae were reared to obtain pupae and adults.

KEY WORDS. Ablabesmyia oliveirai sp. nov.; Brazil; taxonomy.
\end{abstract}

RESUMO. Nova espécie de Ablabesmyia Johannsen (Diptera, Chironomidae,Tanypodinae) da região Neotropical, com descrição do adulto macho e estágios imaturos. É descrita uma nova espécie do gênero Ablabesmyia. As larvas foram coletadas associadas a macrófitas aquáticas de lagoas no Sudeste do Brasil. No laboratório, foram criadas para a obtenção das pupas e adultos.

PALAVRAS-CHAVE. Ablabesmyia oliveirai sp. nov.; Brasil; taxonomia.

The genus Ablabesmyia Johannsen, 1905 is cosmopolitan, except for Antarctica. The genus was established by JohANNSEn (1905), based on Tipula monilis Linnaeus, 1758. It was first treated as a subgenus of Pentaneura Philippi, 1865 by EDWARDs (1927) and JoHANNSEn (1946), called Group A; posteriorly, Freeman (1955) and Rоваск (1959) yet considering it as a subgenus of Pentaneura, but then already bearing the name Ablabesmyia. FITTKaU (1962) recognized the generic status, thus elevating the subgenus to genus (see also Rоваск 1971).

None of the eight species described to Neotropics have been recorded from Brazil (see SpIEs \& Reiss 1996, for the catalogue). However the larvae have been recorded from many ecological studies (Trivinho-STrixino \& Strixino 1995, Takeda et al. 1997, FonseCA-GESSNER \& GUERESCHI 2000, Roque et al. 2003). Recently, Ablabesmyia reissi Paggi \& Suarez, 2000 was described from Argentina and Ablabesmyia electrohispaniolana Grund, 2005 was described from amber of the Dominican Republic.

Due to the lack of information an all life stages, the identification to species level of the Ablabesmyia material is very difficult. The present paper describes and figures all life stages of a new species, Ablabesmyia oliveirai.

\section{MATERIAL AND METHODS}

The larvae of Ablabesmyia oliveirai sp. nov. were collected in small body waters of lentic systems in the São Paulo State, Brazil. They were brought to the laboratory and isolated in small vials with water from the place of collection, in order to obtain the associations between larva, pupa and adults as suggested by Mendes (2002).
The material was mounted in Euparal following the procedures outlined by PINDER $(1983,1986,1989)$. The thorax and abdomen of the adults were cleared in a $10 \% \mathrm{KOH}$ solution. The terminology follows those proposed by SAETHER (1980), ROBACK (1985), Kowalyk (1985) and Langton (1994); the measurements follow EPLER (1988), except for the length of the cephalic capsule of the larva, which was determined by measuring the ventral length from the anterior margin to the post-occipital margin.

The measurements are given as ranges followed by mean when four or more specimens were measured. Measurements are given in $\mu \mathrm{m}$ except when otherwise stated. The type material is deposited at Museu de Zoologia da Universidade de São Paulo (MZSP), São Paulo, Brazil, except for one paratype which is kept at Laboratório de Entomologia Aquática (LEA-UFSCar), Departamento de Hidrobiologia, Universidade Federal de São Carlos, São Paulo, Brazil.

\section{Ablabesmyia oliveirai, sp. nov.}

\section{Figs $1-22$}

Type Material. Holotype (male): BraziL, São Paulo State: Luís Antônio (Estação Ecológica de Jataí, Lagoa Piaba), 30/VIII/1995, S. Trivinho-Strixino leg. Paratypes: 1 male, same data as holotype; 1 male, same data as holotype except for (Lagoa do Óleo), 25/VII/2003; 1 male, Brotas (Lagoa Dourada), 04/III/2004, L. Correia leg.; 1 male with pupal and larval exuviae, São Carlos (represa do Monjolinho), 18/X/2000, L. Correia leg. The paratype with the immature stages associated is deposited in the collection of LEA-UFSCar, the rest of the types are deposited in the MZSP.

Revista Brasileira de Zoologia 23 (3): 740-745, setembro, 2006 


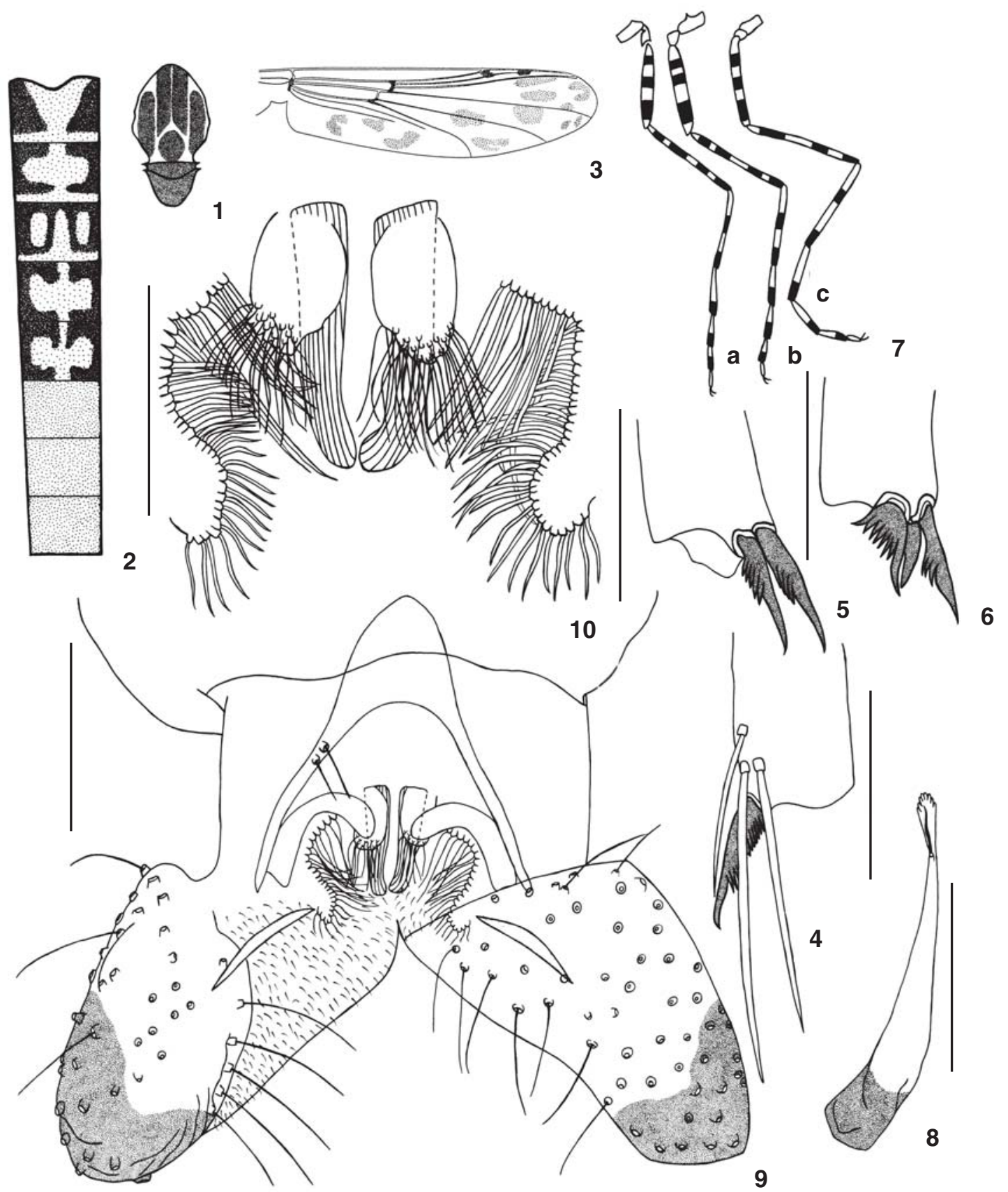

Figures 1-10. Male adult: (1) thorax; (2) abdomen; (3) wing; (4) spur and three pseudospurs, fore leg; (5) spur, middle leg; (6) spur, hind leg; (7) pigmentation pattern of legs; (8) gonostylus with megaseta and pre-apical seta; (9) hypopygium, ventral left half and dorsal right half; (10) volsellas. (a) fore leg; (b) middle leg; (c) hind leg. The drawing thorax, abdomen, wing and legs are design. Scale: $4-6$ and $8-10=0.1 \mathrm{~mm}$.

Etymology. The new species is named in memory and honor of Dr. Sebastião José de Oliveira, in memoriam, Fundação Nacional do Instituto Oswaldo Cruz, Rio de Janeiro, Brazil, to acknowledge his important contributions to the study of the
Brazilian Chironomidae.

Diagnosis. Ablabesmyia oliveirai sp. nov., shares with Ablabesmyia monilis (Linnaeus, 1758), Ablabesmyia metica Roback, 1983 and Ablabesmyia reissi Paggi \& Suarez, 2000, the spoon- 

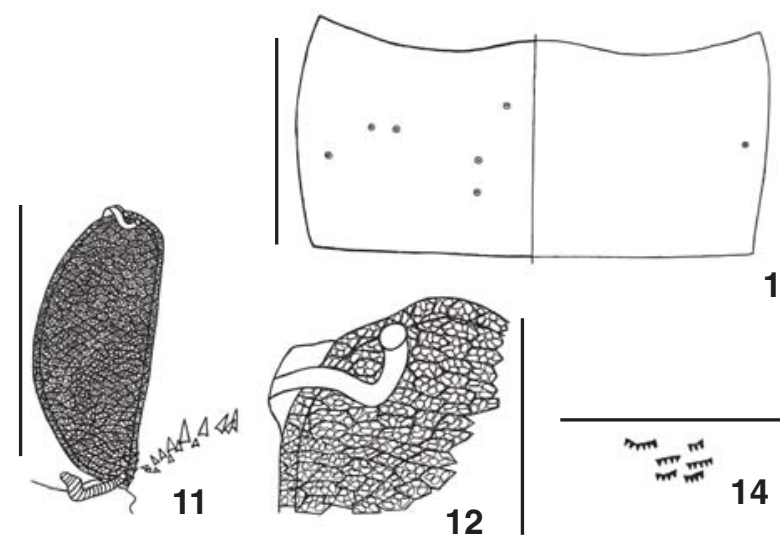

13

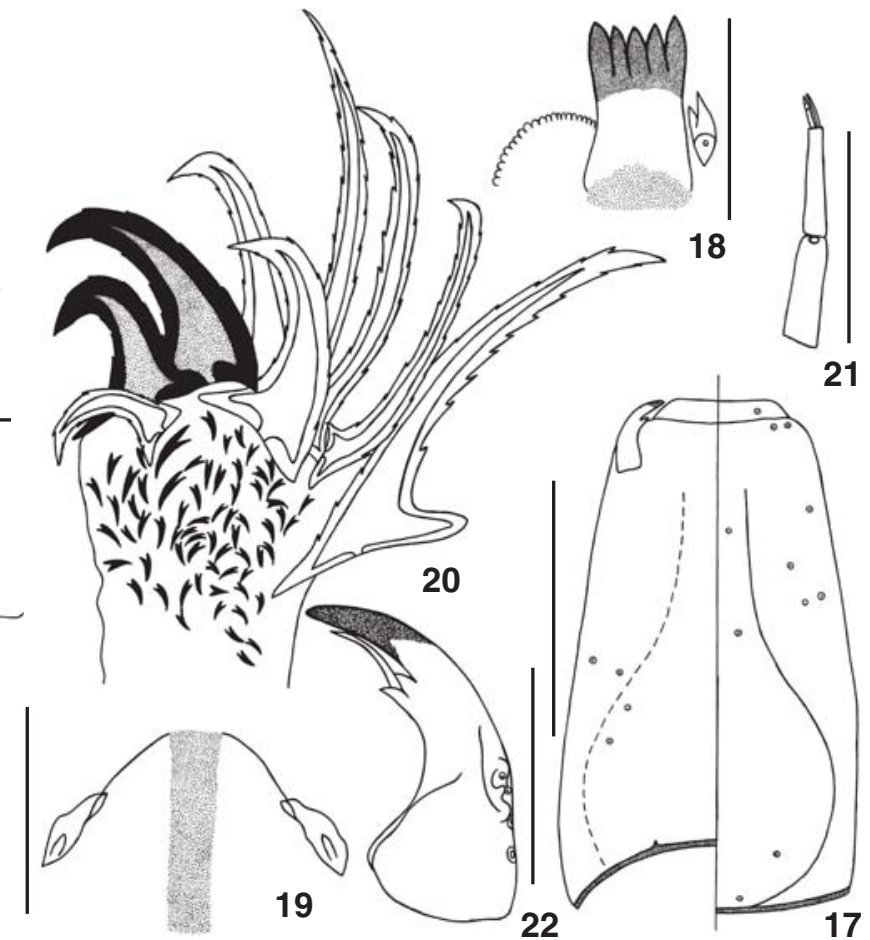

16

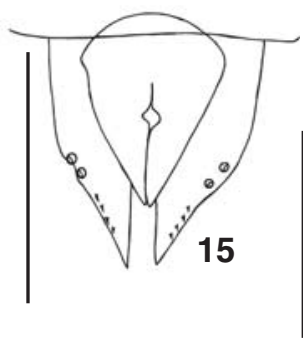

Figures 11-22. (11-16) Pupa: (11) thoracic horn with basal lobe and medial row of teeth; (12) apex of thoracic horn showing aeropyle tube; (13) setal arrangement on AIV, dorsal right half and ventral left half; (14) shagreen; (15) anal lobe and genital sac; (16) frontal apotome. Scale: 11,13 and $15=0.5 \mathrm{~mm} ; 12,14$ and $16=0.1 \mathrm{~mm}$; 17-22. Larva: (17) head capsule, ventral right half and dorsal left half, showing distribution of cephalic setae and pores; (18) ligula with pecten hypopharyngis and paraligula; (19) dorsomental teeth and pseudoradula; (20) some apical claws of posterior parapods; (21) maxillary palp; (22) mandible. Scale: $17=0.5 \mathrm{~mm}$; 18-22 =0.1 mm.

shaped gonostylo megaseta; and with Ablabesmyia electrohispaniolana Grund, 2005, the third palpomere longer than the second; but can it be recognized by the combination of middle leg tibia with three spurs, one pectinated, one lyrate and a third, smooth; tarsomere 1 of hind leg with 6-12 spines linearly set along the inner margin and different volsellae; round superior volsella with abundant long terminal filaments, striated long median volsella with round apex, and inferior volsella in S-shaped.

The pupae can be recognized by the shape of the thoracic horn, with distinct reticulate pattern, sinuous aeropyle tube and club-shaped apex; abdominal setae distribution; and shape and pattern of shagreen.

The larvae can be recognized by the concave apices teeth of the ligula, the two-segmented maxillary palps and the posterior parapods with five hooked and two dark brown claws.

Male imago $(\mathrm{n}=5)$.

Abdominal length 3.26-4.50 mm.

General coloration brown. Head and thorax (Fig. 1) brown. Wings (Fig. 3) membrane transparent, veins darker, with 11-13 brownish spots and five dark brown areas around the arculus, $\mathrm{R}_{2}$ and $\mathrm{R}_{3}$ and the tranversal veins $\mathrm{r}-\mathrm{m}$ and $\mathrm{m}$-cu. Legs yellow with brown bands (Fig. 7). Femur I with three to four bands, one sub- basal, one or two median bands and another pre-apical. Femurs II and III with three bands, one sub-basal, one median and another pre-apical. Tibiae I and II with four bands, one sub-basal, two median and one apical. Tibia III with three bands, one subbasal, one median and another apical. Tarsomeres 1 with two bands, one median and another apical, tarsomeres 2-4 with one apical band and tarsomeres 5 pale. Abdomen pigmented (Fig. 2). Hypopygium yellow (Fig. 9), gonocoxite in apical region brown and gonostylus in basal region brown.

Head. Antennal flagellum $=1.34-1.49 \mathrm{~mm}, \mathrm{AR}=0.10$. Lengths of palpomeres (in $\mu \mathrm{m}$ ): 58-87, 101-136, 161-167, 160167, 330-362. Thorax. Acrostichals divided into 59-60 anterior and 6-10 posterior; 25-35 dorsocentrals; 1 supra-alar; 1 prealar, 8 humerals. Scutellum with 16-28 setae in a double row. Wing. with macrotrichia, Length $1.70-2.35 \mathrm{~mm}$, width 0.50 $0.74 \mathrm{~mm}, \mathrm{WW}=0.29-0.31$, costal extension 1.53-2.18 mm, squama with 28-30 setae. Legs. Fore leg: $\mathrm{LR}_{1}=0.73$; tibia with one pectinated spur of $52-67 \mu \mathrm{m}$ and with three pseudospurs of 70-89, 150-153 and 159-164 $\mu \mathrm{m}$ (Fig. 4), tarsomeres 1 and 2 with two pseudospurs each of 64-72, 70-76, 64-70, 66-71 $\mu \mathrm{m}$ respectively and tarsomeres 3 with one pseudospur of 60-65 $\mu \mathrm{m}$. Middle legs: $\mathrm{LR}_{2}=0.88$; tibia with three spurs, one pectinated

Revista Brasileira de Zoologia 23 (3): 740-745, setembro, 2006 
spur of 59-63 $\mu \mathrm{m}$, other in lyrated of 37-58 $\mu \mathrm{m}$ and one smooth spur of 29-32 $\mu \mathrm{m}$ (Fig. 5), tarsomeres 1 and 2 with two pseudospurs each of 63-73, 62-70 $\mu \mathrm{m}$ and 65-70, 60-69 $\mu \mathrm{m}$ respectively and tarsomeres 3 with one pseudospur of $63-70 \mu \mathrm{m}$. Hind legs: $\mathrm{LR}_{3}=0.90$; tibia with two pectinated spurs of 50-67, 65-89 $\mu \mathrm{m}$ (Fig. 6), tarsomeres 1 with two apical pseudospurs of 75 $81,75-83 \mu \mathrm{m}$ and 6-12 spines linearly set along its inner margin of tarsomeres, tarsomeres 2 with two pseudospurs of 67 $73,60-72 \mu \mathrm{m}$ and tarsomeres 3 with one pseudospur of 61 $69 \mu \mathrm{m}$. Leg measurements and ratios (Tab. I).

Table I. leg. measurements $(\mu \mathrm{m})$ and ratios for holotype $A$. oliveirai sp. nov.

\begin{tabular}{ccccccccc}
\hline & Fe & Ti & Ta1 & Ta2 & Ta3 & Ta4 & Ta5 & LR \\
\hline PI & 953 & 956 & 706 & 318 & 225 & 156 & 118 & 0.73 \\
PII & 725 & 750 & 662 & 375 & 275 & 276 & 153 & 0.88 \\
PIII & 693 & 762 & 687 & 387 & 268 & 212 & 125 & 0.90 \\
\hline
\end{tabular}

Hypopygium (Figs 8-10). Tergite IX 84-93 $\mu \mathrm{m}$ and two or three dorsal setae, gonocoxite 140-200 $\mu \mathrm{m}$, gonostylus 118 $193 \mu \mathrm{m}$, megaseta 24-35 $\mu \mathrm{m}$ spoon-shaped, slender pre-apical seta, $\mathrm{gc} / \mathrm{gs}=1.0-1.1$, transverse sternapodeme 25-69 $\mu \mathrm{m}$, phallapodeme 63-80 $\mu \mathrm{m}$, superior volsella 53-63 $\mu \mathrm{m}$, median volsella $26-27 \mu \mathrm{m}$, inferior volsella 61-41 $\mu \mathrm{m}$.

\section{Pupa ( $\mathrm{n}=1)$}

General coloration yellowish. Thoracic horn with brownish respiratory atrium.

Cephalothorax. Wing sheath $=1.46 \mathrm{~mm}$, oval thoracic horn (Fig. 11), length $537 \mu \mathrm{m}$, width $237 \mu \mathrm{m}$, reticulation of atrium respiratory distinct and homogeneous lumen, membranous apical nipple, $\mathrm{AN}_{\mathrm{i}}=16 \mu \mathrm{m}, \mathrm{AN}_{\mathrm{i}} / \mathrm{TH}=0.029$, aeropyle tube sinuate and apex club-shaped (Fig. 12), plastron plate present, basal lobe produced as conical evagination of the tegument, thoracic comb with 14-16 conic teeth, frontal apotome (Fig. 16).

Abdomen. Tergites entirely covered with shagreen, consisting of small spinules in convex arc (Fig. 14). All segments with abundant setae irregularly distributed. AIV (Fig. 13) with $\mathrm{D}_{1}$ median followed posteriorly by $\mathrm{D}_{3}$ and $\mathrm{D}_{5}$ respectively; $\mathrm{D}_{2}$ lateral to $\mathrm{D}_{4} ; \mathrm{L}_{1}$ posterior to $\mathrm{L}_{2} \mathrm{AV}$-VII with a small prominence at dorsal surface. AVII with four taeniae, position $\mathrm{LS}_{1}=162 \mathrm{~mm}$ of basal region, AVIII with five taeniae, position $\mathrm{LS}_{1}=118 \mu \mathrm{m}$ of basal region. Anal lobe (Fig. 15) elongate, triangular, length $450 \mu \mathrm{m}$, with two taeniae, position $\mathrm{LS}_{1}=231 \mu \mathrm{m}$ of basal region, inner margins with thin spinules. Genital sac (Fig. 15) elongate, conical, length $375 \mu \mathrm{m}$.

\section{$4^{\text {th }}$ instar larva $(\mathrm{n}=1)$}

General coloration yellow. Apex of mandible, ligula and postoccipital margin dark brown. Posterior parapods with two brown apical claws and the others yellow (Fig. 20).

Head capsule (Fig. 17). Elongate. I/C = 1.27. Chaetotaxy of cephalic setae as follows: DORSAL $\left(\mathrm{S}_{1}-\mathrm{S}_{5}, \mathrm{~S}_{11}\right)$ : $\mathrm{S}_{1}$ located near anterior margin, $S_{2}$ and $S_{3}$ located in frontoclypeolabral apotome, $\mathrm{S}_{4}$ anterior to $\mathrm{S}_{5}$, both located on frontal apotome, seta coronal $\mathrm{S}_{11}$ antero-lateral pore coronal. Lateral $\left(\mathrm{S}_{6}-\mathrm{S}_{8}\right): \mathrm{S}_{6}$ postero-lateral to $S_{3}$ followed posteriorly by $S_{7} S_{8}$ postero-lateral to $S_{7}$ Ventral $\left(\mathrm{S}_{9}-\mathrm{S}_{10}, \mathrm{SS}_{\mathrm{m})}: \mathrm{S}_{9}\right.$ antero-lateral to $\mathrm{S}_{10}$. Seta sub-mental $\mathrm{SS}_{\mathrm{m}}$ posterior $\mathrm{S}_{10}$. Ventral pore located between $\mathrm{S}_{10}$ and SS $\mathrm{S}_{\mathrm{m}}$ Dorsal pore near to $\mathrm{S}_{8}$. Coronal pore located near to postoccipital margin. Antenna: $\mathrm{A}_{1} 550 \mu \mathrm{m}$, ring organ located $306 \mu \mathrm{m}$ from base. Maxilla (Fig. 21): maxillary palps with two segments, $P_{1} / P_{2}=1.0$, ring organ located in $\mathrm{P}_{1} 46 \mu \mathrm{m}$ from base. Mandible (Fig. 22): length 153 $\mu \mathrm{m}$, with three lateroventrals setae and one sensilium campaniforme located $118 \mu \mathrm{m}$ at apice, basal tooth bifide with a seta subdentalis, $\mathrm{A1} / \mathrm{MD}=3.59$. Mentum (Fig. 19): dorsomental teeth, pseudoradula uniformly granulate. Hypopharyngeal complex (Fig. 18): ligula $92 \mu \mathrm{m}$, with five teeth forming a concave toothed margin, tooth outcurved, basal third granulose, base as width as teeth width, $\mathrm{It} / \mathrm{O}=0.91, \mathrm{Mt} / \mathrm{O}=0.88$; paraligula 35 $\mu \mathrm{m}$, bifid, pecten hypopharyngis with 21 small teeth in an arc. Abdomen: without lateral fringe, procercus $147 \mu \mathrm{m}$; with seven anal setae, length $825 \mu \mathrm{m}$; supra-anal setae simple, length 443 $\mu \mathrm{m}$. Posterior parapods (Fig. 20) with apical claws serrated outer margin, five hooked claws and two dark brown and in region apical with hooklets.

\section{DISCUSSION}

Rоваск (1959) divided the subgenus Ablabesmyia into two groups, monilis and illinoensis. The major differences of the groups is the shape of the megaseta, which is spoon-shaped in the monilis group and slender in the illinoensis group. Later, in 1971, the same author created two subgenera by grouping the species of these groups, the subgenus Ablabesmyia for the monilis group and the subgenus Karelia for the illinoensis group. Rоваск (1983) proposed the subgenus Sartaia based only on adults, for the A. metica species from the Neotropical region. And in 1985, he proposed the subgenus Asayia for A. annulata (Say, 1823).

The division proposed by Rоваск (1959) and confirmed by Murray \& Fittkau (1989), states that the species with spoonshaped megaseta belong in the subgenus Ablabesmyia, yet according to Rоваск (1985), larvae with two-segmented maxillary palps should be placed in the subgenus Karelia. The present species fits both subgenera, considering the larval and adult stages.

The pupae of Ablabesmyia oliveirai sp. nov. does not readily fit into any of the three subgenera proposed by Rоваск (1985), Ablabesmyia, Karelia and Asayia, as it shares sinuous aeropyle tube and club-shaped apex with Ablabesmyia and respiratory atrium with distinct reticulation with Karelia.

A similar problem was reported by PAGgi \& SuARez (2000) for Ablabesmyia reissi. Probably Ablabesmyia oliveirai sp. nov., could be better included in the "reissi group" proposed by these authors, although the larvae of $A$. oliveirai sp. nov. lack the palpiger (membranous portion between $\mathrm{P}_{1}$ and $\mathrm{P}_{2}$ ), characteristic that defines this group.

Revista Brasileira de Zoologia 23 (3): 740-745, setembro, 2006 


\section{Ecological notes}

The specimens were collected in three ponds and in a reservoir, all of them located in three counties in the central São Paulo State, Brazil. The ponds Piaba and Óleo are located in the Ecological Station of Luís Antônio $\left(21^{\circ} 36^{\prime} \mathrm{S}, 47^{\circ} 48^{\prime} \mathrm{W}\right)$, the pond Dourada in the county of Brotas and the Monjolinho reservoir in the county of São Carlos $\left(21^{\circ} 53^{\prime} \mathrm{S}, 47^{\circ} 52^{\prime} \mathrm{W}\right)$.

The larvae of Ablabesmyia oliveirai were collected associated with aquatic macrophytes of the genera: Eichhornia, Egeria, Myriophyllum, Scirpus, and Cabomba of shallow lakes (0.4-2.9 $\mathrm{m})$ with well-oxygenated water $\left(6.8-7.2 \mathrm{mgL}^{-1}\right)$.

The larvae of genus Ablabesmyia are predators, feeding on small invertebrates, including other Chironomidae larvae. Generalist insectivore fishes can eat these larvae, for example of Crenicichla britskii (Perciformes, Cichlidae) (GIBRAN et al. 2001).

\section{ACKNOWLEDGEMENTS}

To Susana Trivinho-Strixino, Humberto F. Mendes, and Programa de Pós-Graduação em Ecologia e Recursos Naturais (PPG-ERN/UFSCar).

\section{REFERENCES}

EDWARDS, F.W. 1927. British non-biting midges (Diptera, Chironomidae). Transactions of the Entomological Society of London, London, 77: 279-430.

EPLER, J.H. 1988. Biosystematics of the genus Dicrotendipes Kieffer, 1913 (Diptera: Chironomidae: Chironominae) of the World, Memoirs of the American Entomological Society, Philadelphia, 36: 18-31.

FITTKAU, E.J. 1962. Incluir referência completa seguindo as Instruções aos Autores ou retirar a citação do texto.

FonseCA-GeSSNER, A.A \& R.M. GuERESCHI. 2000. Macroinvertebrados bentônicos na avaliação da qualidade da água de três córregos na Estação Ecológica de Jataí, Luiz Antônio, SP, Brasil, p. 707720. In: J.E. SANTOS \& J.S.R. PIRES (Eds). Estação Ecológica de Jataí: estudos integrados em ecossistemas. São Carlos, RIMA, vol. 2, XVIII+867p.

Freeman, P. 1955. A study of the Chironomidae (Diptera) of Africa south of the Sahara. Bulletin of the British Museum (Natural History) Entomology, London, 4 (1): 1-67

Gibran, F.Z; K.M. FerReira \& R.M.C. Castro. 2001. Diet of Crenicichla britskii (Perciformes: Cichlidae) in a steram of Rio Aguapeí basin, upper rio Paraná system, southeastern Brazil. Biota Neotropica,? Deve ser informado o link completo para o artigo e data de acesso - vide Instruções aos Autores, 1.

JohanNSEn, O.A. 1905. Aquatic Nematocerous Diptera. Bulletin of New York State Museum, New York, 86: 328-441.

Johannsen, O.A. 1946. Revision of the north american species of the genus Pentaneura (Tendipedidae: Chironomidae, Diptera). Journal of the New York Entomological Society, New York, 54: 268-287.

KoWALYK, H.E. 1985. The larval cephalic setae in the Tanypodinae
(Diptera: Chironomidae) and their importance in generic determinations. The Canadian Entomologist, Ottawa, 117 (1): 67-106.

LANGTON, P.H. 1994. If not "filaments" then what? Chironomus Newsletter, Canberra, 6: 9

Mendes, H.F. 2002. Rearing Tanypodinae, Telmatogetoninae and Orthocladiinae in Brazil - an empirical approach. Chironomus Newsletter, Camberra, 15: 29-32.

MurRAY, D.A \& E.J. FitTKAu. 1989. The adult males of Tanypodinae (Diptera: Chironomidae) of the Holarctic region - keys and diagnoses. Entomologia Scandinavica Supplements, Sandby, 34: 37-123.

Paggi, A.C. \& D.A.A. Suarez 2000. Ablabesmyia reissi spec. nov., a new species of Tanypodinae from Rio Negro province, Argentina, with descriptions of the adult female and preimaginal stages. Spixiana, Munchen, 23 (3): 259-266.

Pinder, L.C.V. 1983. The larvae of Chironomidae (Diptera) of the Holartic region - Introduction. Entomologia Scandinavica Supplement, Sandby, 19: 7-10.

PINDER, L.C.V. 1986. The pupae of Chironomidae (Diptera) of the Holartic region - Introduction. Entomologia Scandinavica Supplement, Sandby, 28: 5-7.

PINDER, L.C.V. 1989. The adult of Chironomidae (Diptera) of the Holartic region - Introduction. Entomologia Scandinavica Supplement, Sandby, 34: 5-9.

Rоваск, S.S. 1959. The subgenus Ablabesmyia of Pentaneura (Diptera, Tendipedidae, Pelopiinae). Transactions of the American Entomological Society, Philadelphia, 85: 113-135.

Rоваск, S.S. 1971. The adults of the subfamily Tanypodinae (= Pelopinae) in North America (Diptera: Chironomidae). The Academy of Natural Sciences of Philadelphia $19^{\text {th }}$ and the Parkway Philadelphia, Pennsylvania, 17: 1-410.

Rоваск, S.S. 1983. Ablabesmyia (Sartaia) metica a new subgenus and species (Diptera: Chironomidae: Tanypodinae). Proceedings of the Academy of Natural Sciences of Philadelphia, Pennsylvania, 135: 236-240.

Rоваск, S.S. 1985. The immature Chironomids of the eastern United States.VI. Pentaneurini-genus Ablabesmyia. Proceedings of the Academy of Natural Sciences of Philadelphia, Philadelphia, 137 (2): 153-212.

Roque F. O.; S. Trivinho-Strixino; M.V. Yamada \& A.M. PenteadoDiAs. 2003. A preliminary survey of Chironomidae adults (Insecta: Diptera) in a heterogeneous landscape of Jaraguá State Park, São Paulo, Brasil. Biotemas, Santa Catarina, 16 (2): 67-78.

SAETHER, O.A. 1980. Glossary of chironomid morphology terminology (Diptera: Chironomidae). Entomologica Scandinavica Supplements, Sandby, 14: 1-51.

SPIES, M. \& F. ReIss 1996. Catalog and bibliography of Neotropical and Mexican Chironomidae (Insecta, Diptera). Spixiana Supplement, Munchen, 22: 61-119.

TAKEDA, A.M.; G.Y. ShHYMisu \& J. Higuti. 1997. Variação espaçotemporais da comunidade zoobêntica, p. 157-177. In: A.E.A.M. Vazzoler; A.A.Agostinho \& N.S. Hahn (Eds). A Planície de

Revista Brasileira de Zoologia 23 (3): 740-745, setembro, 2006 
Inundação do Alto Rio Paraná: aspectos físicos, biológicos e socioeconômicos. Maringá, Universidade Estadual de Maringá, XII+460p.

Trivinho-Strixino, S. \& G. STriXINo. 1995. Larvas de Chironomi- dae (Diptera) do Estado de São Paulo: guia de identificação e diagnose dos gêneros. São Carlos, Programa de Pósgraduação em Ecologia e Recusrsos Naturais, Universidade Federal de São Carlos, 229p.

Received in 10.I.2006; accepted in 23.VIII.2006. 